\title{
A Eulogy to Adam Kondorosi
}

\section{J. Allan Downie}

John Innes Centre, Colney, Norwich NR4 7UH, U.K.

It is a privilege and an honor to be asked to give this tribute to Adam Kondorosi, who died in January this year. I would like to use this opportunity to try to draw a picture of Adam and the contributions he made as a scientist and as a person. I speak on behalf of many colleagues, too many to name. Several of you will have known Adam, but I am confident that even those of you who did not know him will have been influenced by his significant scientific contributions to plant-microbe interactions, focused around legume nodulation by rhizobia. In addition to understanding the specifics of this symbiosis, he used his research as a platform on which he could draw broad conclusions about biology in general and I will try to highlight key findings here.

I first met Adam and his wife Eva in 1982 in Cologne on the way to a conference. Without knowing me, they happily invited me, along with my colleagues, into their home, establishing the basis for a long friendship.

Adam earned his first degree and Ph.D. at the University of Budapest, where, according to Ilona Dusha, one of his fellow students, "it was obvious already from the beginning that he was one of the best if not THE best student among us." Adam completed his Ph.D. on the genetics of rhizobiophage in 1972; thus, Adam embarked on a career in genetics at a time when the shadow of Trofim Lysenko's politically motivated pseudoscientific approach still hung over research in genetics in Eastern Europe. At about this time, the Institute of Genetics was set up in Szeged by the Hungarian Academy of Sciences and Adam was one of a highly select group of young scientists recruited there. Shortly after that, Adam went to work at the Unit of Nitrogen Fixation at the University of Sussex. Although he was newly married, his wife Eva was required by the authorities to remain in Hungary in order to ensure Adam's return to Hungary. After their first wedding anniversary, Eva's passport and visa finally arrived and she was able to join Adam at the Unit of Nitrogen Fixation where they shared a small laboratory, which was fondly referred to by their colleagues as the 'Garden of Eden' or 'Paradise'. They returned to Szeged in 1976 when Adam became head of the Nitrogen Fixation Group, and in 1984, he became deputy director of the Institute.

At the end of 1981, a fruitful and friendly collaboration began with Jeff Schell, who asked Adam to introduce and lead Rhizobium-legume research at the Max Planck Institute in Cologne. This was supported by the European Molecular Biology Organization (EMBO) (1981-1982) and Humboldt (1988) fellowships and Deutsche Forschungsgemeinschaft grants (19831987) that allowed frequent visits between the German and Hungarian groups. Adam was appointed in 1989 as Director of the Centre National de la Recherche Scientifique Institut des Sciences Végétales (ISV) in Gif-sur-Yvette, where he encouraged the development of several new and effective research

Corresponding author: J. Allan Downie: Telephone: +1 (44)-1603 450207; E-mail: Allan.Downie@jic.ac.uk programs. During his career, Adam was a leading member of the scientific establishment and was elected as a member of the Hungarian Academy of Sciences, The Academy of Europe, and EMBO and won awards including the United Nations Educational, Scientific and Cultural Organization J C Finlay prize and the Szécheni prize in Hungary.

One of the hallmarks of Adam's research was the building of genetic tools. In his early research on Sinorhizobium meliloti, he developed rhizobiophage for use in transfection and transduction (Kondorosi et al. 1974; Orosz et al. 1973). Identifying mutants unable to reduce nitrate showed that there were common requirements for nitrate reduction and nitrogen fixation (Kondorosi et al. 1973).

During the period that Adam worked at the Unit of N-fixation at the University of Sussex, he made a significant contribution to using in vivo recombination to generate large stable transmissible $\mathrm{P}$ plasmids carrying the $\mathrm{N}$-fixation (nif) genes from Klebsiella pneumoniae (Dixon et al. 1976). This preceded the advent of in vitro cloning methods, and the significance of this work was that the plasmid could be transferred across wide genetic boundaries (including into rhizobia) and that the plasmid was stable enough to allow genetic complementation tests to be done in $K$. pneumoniae. This led to the identification of most of the nitrogen fixation genes in $K$. pneumoniae (Dixon et al. 1977).

By establishing equivalent genetic tools ( $\mathrm{R}$ primes) to mobilize DNA in rhizobia, he showed by classical genetics that there was a circular chromosome in S. meliloti (Kondorosi et al. 1977). S. meliloti is alongside Rhizobium and Agrobacterium spp. in the division of $\alpha$-proteobacteria, and at that time, there was relatively little bacterial genetics being done with $\alpha$ proteobacteria; most bacterial genetics at that time was being
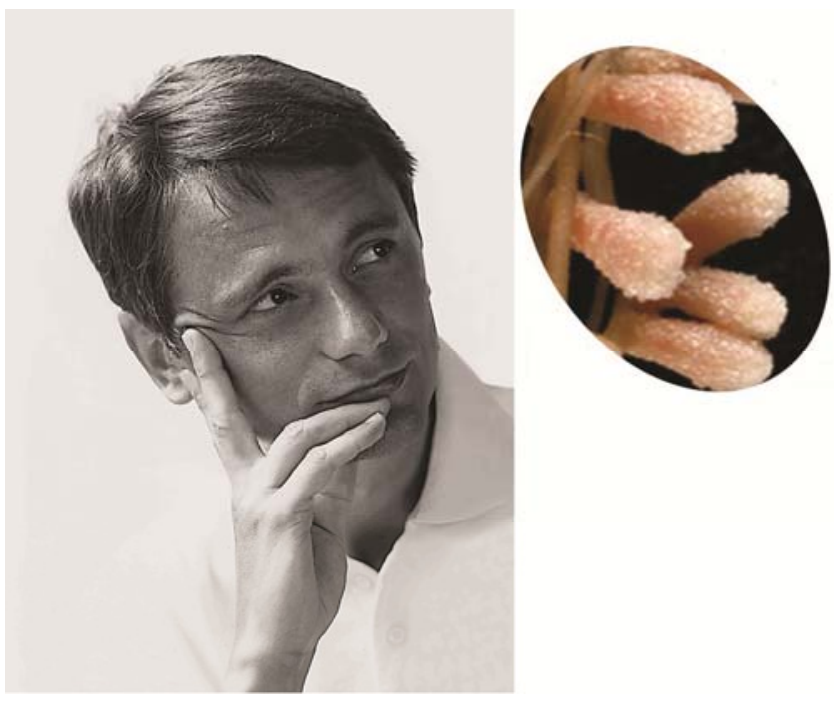

Adam Kondorosi in a contemplative mood. 
done with $\gamma$-proteobacteria and a few other gram-positive bacteria. Therefore, genetic tools had to be generated de novo or adapted from other bacteria, and Adam's work paralleled other developments in rhizobial and agrobacterial genetics. Adam's genetic work led to transfer of large regions of DNA and comparability of genomes between rhizobia (Kondorosi et al. 1980).

The tools developed for DNA mobilization revealed that the $S$. meliloti nodulation and nitrogen-fixation genes are located on a large megaplasmid (Bánfalvi et al. 1981); significantly, despite his many papers published in high-profile journals, this publication in Molecular and General Genetics is Adam's most-cited paper, so perhaps young scientists can take heed of the fact that publication of good research papers can have a high impact even if they are not in the most fashionable journals. The mobilization of the symbiosis genes then led to the recognition that it was possible to transfer the symbiosis phenotype, even to agrobacteria, outside of the recognized rhizobia (Wong et al. 1983). This early phase of Adam's research showed that i) there was a shared pathway in nitrate reduction and nitrogen fixation, ii) genetics in the $\alpha$-proteobacteria could be done and iii) that symbiosis genes could be mobilized across genetic boundaries.

Adam followed up his interest in nif genes by sequencing the nitrogenase reductase gene nifH from $S$. meliloti (Torok and Kondorosi 1981). DNA sequencing at this time was not simple and, due to limited availability of materials in Hungary, Adam's group had the additional hurdle of having to synthesize the $\mathrm{P}^{32}$-labeled ATP needed for the DNA sequencing. This gives an insight into just how determined Adam was. This paper also carried the message that the Institute of Genetics in Szeged was already a significant player in the newly developing field of molecular genetics.

Using these developing skills in molecular biology, Adam's group in Szeged started to work on the nodulation genes and their role in host-specific legume nodulation. This led to identification of the nodulation (nod) genes (Kondorosi et al. 1984) and the subsequent analysis of their induction by flavonoids and their biochemical functions in relation to production of lipo-chitooligosaccharide Nod factors (Schultze and Kondorosi 1998). An early finding was the identification (by oligonucleotide hybridization) of six extended nod-gene promoter regions (nod boxes) in S. meliloti (Rostas et al. 1986) and their importance as sites for induction by the regulator NodD. This was important because it defined limits on the search for nod genes and assisted the identification of the full complement of the nod genes, the functions of the proteins, and their importance in host-specific nodulation (Horvath et al. 1986, 1987; Kondorosi et al. 1984). Adam was particularly interested in the subgroup of nodulation genes determining host specificity, and our discussions on these genes revealed to me just how firm Adam could be when he decided to make a point.

Other significant findings from Adam's group in this period included the importance of negative as well as positive regulation of the nod genes (Kondorosi et al. 1989, 1991) and the identification of a family of related Nod factors (Schultze et al. 1992, 1995). In parallel with this work on nod genes and Nod factors, Adam and his colleagues clearly recognized the importance of surface polysaccharides in nodulation (Kereszt et al. 1998; Kiss et al. 1997; Petrovics et al. 1993; Putnoky et al. 1990), including a novel type of capsular polysaccharide.

Adam's move to the ISV in Gif-sur-Yvette in 1989 was accompanied by a much stronger focus on the plant partner in the symbiosis, initially focusing on the early responses to rhizobia. A collaboration with Hubert Felle revealed that there was an influx of $\mathrm{Ca}^{++}$across the root-hair membrane accompanied by an $\mathrm{H}^{+}$influx and an efflux of $\mathrm{K}^{+}$and $\mathrm{Cl}^{-}$, resulting in the depolarization of the membrane, as had been observed previously by Dave Ehrhardt in Sharon Long's group in Stanford. This series of papers (Felle et al. 1995, 1996, 1998, 1999a and $b, 2000)$ defined the specific ion fluxes and the role of different Nod factors in their induction.

Analysis of other early responses developed an understanding of the role of plant chitinases on Nod-factor stability (Staehelin et al. 1994, 1995, 2000), the demonstration that the $\mathrm{N}$ status of roots influences the production of flavonoids (and hence nodgene induction by rhizobia) (Coronado et al. 1995), and the recognition that there are at least two programs activated by plants in response to Nod factors (Bauer et al. 1996, 1997; Charon et al. 1997, 1999; Chen et al. 2005; Crespi et al. 1994).

One of the areas that Adam helped develop following the move to the ISV at Gif-sur-Yvette was the analysis of the activation of the cell cycle associated with the initiation of nodule morphogenesis. In a series of landmark papers (Kondorosi et al. 2005; Roudier et al. 2000, 2003; Savoure et al. 1994; Tarayre et al. 2004), they identified cyclins, kinases, and other genes that are induced to initiate the cell-cycle activation that is required for the production of a new meristem. This activation was shown to be initiated by cytokinin (Bauer et al. 1996; Kondorosi et al. 2005; Mathesius et al. 2000; Roudier et al. 2000, 2003; Savoure et al. 1994; Tarayre et al. 2004). Adam and his collaborators recognized early that there was a role for noncoding RNA in nodule development, recognizing the importance of ENOD40, which encodes a short peptide and also has a large noncoding RNA domain; this RNA domain plays a role in nodule development and can bind to and cause relocalization of nuclear proteins to the cytoplasm (Campalans et al. 2004; Charon et al. 1997, 1999; Crespi et al. 1994; Mathesius et al. 2000). They also identified a Kruppel-like zinc-finger protein that was critical for the infection of the nodule cells by rhizobia (Frugier et al. 2000).

That work on the cellular differentiation associated with nodule morphogenesis ran alongside other research on differentiation that emerged out of a fusion of research on nodule genomics and bacteroid differentiation. Adam and his collaborators recognized that nodules of Medicago truncatula produced a large number of cysteine-rich peptides that have an N-terminal signal peptide. These could be considered to be similar to some antimicrobial peptides, and they showed that the proteins were translocated across the peribacteroid membrane. This work (Alunni et al. 2007; Mergaert et al. 2003, 2006) led to the recognition that the bacteroid enlargement seen in these nodules is accompanied by bacterial genomic endoreduplication and that this is controlled by the plant-expressed cysteinerich peptides. This has led to a new way of thinking about how the eukaryotic hosts may constrain and control their microbial symbiotic partners.

The last area of Adam's research I would like to deal with returns to the theme of generating genetic tools for research into the rhizobial-legume symbiosis. This was driven by a desire to establish a gene-tagging strategy in M. truncatula, and this required an efficient transformation system. So Adam and his colleagues screened varieties of $M$ truncatula to identify lines that were easily transformed and then developed a robust protocol for generating stable transformed lines (Hoffmann et al. 1997; Trinh et al. 1998). I am aware just how good a system this is because a student in my group was able to use it to generate transgenic plants expressing a calcium monitoring protein. However, although generating stable transgenic reporter plants is useful, the key importance of this work was undoubtedly the use of transformation to develop transposon-tagged mutants of M. truncatula (Benlloch et al. 2006; d'Erfurth et al. 2003). This technology has been further developed together with collaborators at the Noble foundation in Ardmore, Okla- 
homa, where a large population of transposon-tagged mutants has been generated and the sites of insertion are being identified. This will be of enormous importance in all aspects of legume research and has the potential of making $M$. truncatula a fully tractable model research plant that will provide openings in avenues of research complementary to those being pursued with Arabidopsis and rice. This huge achievement, which occurred at the end of Adam's career, reflects the way he started, namely, to generate genetic tools for both partners in the symbiosis.

Such tools, when applied wisely, can lead to understanding concepts in biology. In this eulogy, I have not been able to comment on all aspects of Adam's research. Throughout his career, however, Adam strove to use the study of the symbiosis to provide a window into some of the larger questions in biology, and he and his colleagues made a huge contribution. Many other research groups have also made significant contributions that have not been cited here, but I am sure that those colleagues and competitors will also recognize that, throughout his career, Adam was always in the vanguard of new discoveries and the introduction of new concepts and tools.

My final comments are personal observations on Adam, and these come from a friend, a collaborator, a sometime competitor, and a great admirer. Adam was an exceptional scientist. He was one of the most organized people I have known. When I sat on review panels with him, I knew that he would always be able to put his hand on any document or scrap of information that was needed. Adam appointed excellent people, and the success of the younger scientists appointed at the Institute of Genetics in Szeged and the ISV in Gif-sur-Yvette attests to this. Adam did not simply appoint excellent people, he also mentored them, helped them develop research programs that are significant, and encouraged them to tackle hard and important problems. Adam was a wonderful collaborator, and this is reflected in the great diversity of research that he has published with collaborators from all over the world. As one of them, I can genuinely say that he was a pleasure to work with and he was an exacting and constructive critic of the research outputs.

One of Adam's great strengths was his phenomenal memory, which was underscored to me during a conversation at a scientific meeting. We were discussing some aspect of nodulation signaling when I got a bit carried away and proposed a new idea to Adam. He gently pointed out to me that this was unlikely to be correct, basing his criticism on a relatively minor observation made in one of my own papers. Adam could remember the precise details, and we both just laughed and got on with redefining the issue. According to some of his close colleagues, Adam was able to recall precise scientific definitions that he had learned as an undergraduate student and was also able to recall most of the details of papers that he cited, including the names of most of the coauthors. You can only imagine how a person with such a precise memory felt when (in the early days, before electronic databases of publications) two of the authors on one of his papers had their names somewhat mangled (Bánfalvi became Dansalvi and Forrai became Sorrai). This incorrect citation was propagated for some years (including secondary citations by other authors) until, in the most gentlemanly way, Adam pointed out to the initial perpetrator (Andy Johnston) that perhaps this should be corrected in future publications. Adam was always kind and considerate, even when being critical (as he always was) and, as a result, was a great friend to have. Andy Johnston said of Adam that he was 'A prince among men, and a human being of the highest quality', a statement that all of his friends would agree with.

Adam was a wonderful husband to Eva and father to their daughter Fanny. Throughout Adam's entire scientific life, Eva has been a loving partner and a scientific collaborator of the highest caliber. She and Adam faced many challenges and changes, but they always worked together, both in science and in creating an intimate home life that was open to many friends and collaborators. In Adam's untimely illness and death, I believe that we have lost a great leader who was always a gentleman and a scientist to his very core.

\section{LITERATURE CITED}

Alunni, B., Kevei, Z., Redondo-Nieto, M., Kondorosi, A., Mergaert, P., and Kondorosi, E. 2007. Genomic organization and evolutionary insights on GRP and NCR genes, two large nodule-specific gene families in Medicago truncatula. Mol. Plant-Microbe Interact. 20:1138-1148.

Bánfalvi, Z., Sakanyan, V., Koncz, C., Kiss, A., Dusha, I., and Kondorosi, A. 1981. Location of nodulation and nitrogen-fixation genes on a high molecular weight plasmid of $R$. meliloti. Mol. Gen. Genet 184:318325.

Bauer, P., Ratet, P., Crespi, M. D., Schultze, M., and Kondorosi, A. 1996. Nod factors and cytokinins induce similar cortical cell division, amyloplast deposition and MsEnod12A expression patterns in alfalfa roots. Plant J. 10:91-105.

Bauer, P., Poirier, S., Ratet, P., and Kondorosi, A. 1997. MsEnod12A expression is linked to meristematic activity during development of indeterminate and determinate nodules and roots. Mol. Plant-Microbe Interact. 10:39-49.

Benlloch, R., d'Erfurth, I., Ferrandiz, C., Cosson, V., Beltran, J. P., Canas, L. A., Kondorosi, A., Madueno, F., and Ratet, P. 2006. Isolation of mtpim proves Tnt1 a useful reverse genetics tool in Medicago truncatula and uncovers new aspects of APl-like functions in legumes. Plant Physiol. 142:972-983.

Campalans, A., Kondorosi, A., and Crespi, M. 2004. Enod40, a short open reading frame-containing $\mathrm{mRNA}$, induces cytoplasmic localization of a nuclear RNA binding protein in Medicago truncatula. Plant Cell 16:1047-1059.

Charon, C., Johansson, C., Kondorosi, E., Kondorosi, A., and Crespi, M. 1997. enod40 induces dedifferentiation and division of root cortical cells in legumes. Proc. Natl. Acad. Sci. U.S.A. 94:8901-8906.

Charon, C., Sousa, C., Crespi, M., and Kondorosi, A. 1999. Alteration of ENOD40 expression modifies Medicago truncatula root nodule development induced by Sinorhizobium meliloti. Plant Cell 11:1953-1965.

Chen, H. C., Gao, K., Kondorosi, E., Kondorosi, A., and Rolfe, B. G. 2005. Functional genomic analysis of global regulator NoIR in Sinorhizobium meliloti. Mol. Plant-Microbe Interact. 18:1340-1352.

Coronado, C., Zuanazzi, J. A. S., Sallaud, C., Quirion, J. C., Esnault, R., Husson, H. P., Kondorosi, A., and Ratet, P. 1995. Alfalfa root flavonoid production is nitrogen regulated. Plant Physiol. 108:533-542.

Crespi, M. D., Jurkevitch, E., Poiret, M., Daubentoncarafa, Y., Petrovics, G., Kondorosi, E., and Kondorosi, A. 1994. ENOD40, a gene expressed during nodule organogenesis, codes for a nontranslatable RNA involved in plant growth. EMBO (Eur. Mol. Biol. Organ.) J. 13:5099-5112.

d'Erfurth, I., Cosson, V., Eschstruth, A., Lucas, H., Kondorosi, A., and Ratet, P. 2003. Efficient transposition of the Tnt1 tobacco retrotransposon in the model legume Medicago truncatula. Plant J. 34:95-106.

Dixon, R., Cannon, F., and Kondorosi, A. 1976. Construction of a P plasmid carrying nitrogen-fixation genes from Klebsiella pneumoniae. Nature 260:268-271.

Dixon, R., Kennedy, C., Kondorosi, A., Krishnapillai, V., and Merrick, M. 1977. Complementation analysis of Klebsiella pneumoniae mutants defective in nitrogen fixation. Mol. Gen. Genet. 157:189-198.

Felle, H. H., Kondorosi, E., Kondorosi, A., and Schultze, M. 1995. Nod signal-induced plasma-membrane potential changes in alfalfa root hairs are differentially sensitive to structural modifications of the lipochitooligosaccharide. Plant J. 7:939-947.

Felle, H. H., Kondorosi, E., Kondorosi, A., and Schultze, M. 1996. Rapid alkalinization in alfalfa root hairs in response to rhizobial lipochitooligosaccharide signals. Plant J. 10:295-301.

Felle, H. H., Kondorosi, E., Kondorosi, A., and Schultze, M. 1998. The role of ion fluxes in Nod factor signalling in Medicago sativa. Plant J. 13:455-463.

Felle, H. H., Kondorosi, E., Kondorosi, A., and Schultze, M. 1999a. Nod factors modulate the concentration of cytosolic free calcium differently in growing and non-growing root hairs of Medicago sativa L. Planta 209:207-212.

Felle, H. H., Kondorosi, E., Kondorosi, A., and Schultze, M. 1999b. Elevation of the cytosolic free $\left[\mathrm{Ca}^{2+}\right]$ is indispensable for the transduction of the nod-factor signal in alfalfa. Plant Physiol. 121:273-279.

Felle, H. H., Kondorosi, E., Kondorosi, A., and Schultze, M. 2000. How 
alfalfa root hairs discriminate between Nod factors and oligochitin elicitors. Plant Physiol. 124:1373-1380.

Frugier, F., Poirier, S., Satiat-Jeunemaitre, B., Kondorosi, A., and Crespi, M. 2000. A Kruppel-like zinc finger protein is involved in nitrogen-fixing root nodule organogenesis. Genes Dev. 14:475-482.

Hoffmann, B., Trinh, T. H., Leung, J., Kondorosi, A., and Kondorosi, E. 1997. A new Medicago truncatula line with superior in vitro regeneration, transformation, and symbiotic properties isolated through cell culture selection. Mol. Plant-Microbe Interact. 10:307-315.

Horvath, B., Kondorosi, E., John, M., Schmidt, J., Torok, I., Gyorgypal, Z., Barabas, I., Wieneke, U., Schell, J., and Kondorosi, A. 1986. Organisation, structure and symbiotic function of Rhizobium meliloti nodulation genes determining host specificity for alfalfa. Cell 46:335-343.

Horvath, B., Bachem, C. W. B., Schell, J., and Kondorosi, A. 1987. Hostspecific regulation of nodulation genes in Rhizobium is mediated by a plant signal interactiong with the nodD gene product. EMBO (Eur. Mol. Biol. Organ.) J. 6:841-848.

Kereszt, A., Kiss, E., Reuhs, B. L., Carlson, R. W., Kondorosi, A., and Putnoky, P. 1998. Novel rkp gene clusters of Sinorhizobium meliloti involved in capsular polysaccharide production and invasion of the symbiotic nodule: The $r k p K$ gene encodes a UDP-glucose dehydrogenase. J. Bacteriol. 180:5426-5431.

Kiss, E., Reuhs, B. L., Kim, J. S., Kereszt, A., Petrovics, G., Putnoky, P., Dusha, I., Carlson, R. W., and Kondorosi, A. 1997. The rkpGHI and J genes are involved in capsular polysaccharide production by Rhizobium meliloti. J. Bacteriol. 179:2132-2140.

Kondorosi, A., Barabas, I., Svab, Z., Orosz, L., Sik, T., and Hotchkis.Rd. 1973. Evidence for common genetic determinants of nitrogenase and nitrate reductase in Rhizobium meliloti. Nature 246:153-154.

Kondorosi, A., Orosz, L., Svab, Z., and Sik, T. 1974. Genetic studies on rhizobiophage 16-3: 2. helper-induced transfection. Mol. Gen. Genet 132:153-163.

Kondorosi, A., Kiss, G. B., Forrai, T., Vincze, E., and Bánfalvi, Z. 1977. Circular linkage map of Rhizobium meliloti chromosome. Nature 268:525-527.

Kondorosi, A., Vincze, E., Johnston, A. W. B., and Beringer, J. E. 1980. A comparison of three Rhizobium linkage maps. Mol. Gen. Genet. 178:403-408.

Kondorosi, E., Bánfalvi, Z., and Kondorosi, A. 1984. Physical and genetic analysis of a symbiotic region of Rhizobium meliloti - identification of nodulation genes. Mol. Gen. Genet. 193:445-452.

Kondorosi, E., Gyuris, J., Schmidt, J., John, M., Duda, E., Hoffmann, B., Schell, J., and Kondorosi, A. 1989. Positive and negative control of nod gene expression in Rhizobium meliloti is required for optimal nodulation. EMBO (Eur. Mol. Biol. Organ.) J. 8:1331-1340.

Kondorosi, E., Pierre, M., Cren, M., Haumann, U., Buire, M., Hoffmann, B., Schell, J., and Kondorosi, A. 1991. Identification of NolR, a negatively transacting factor controlling the nod regulon in Rhizobium meliloti. J. Mol. Biol. 222:885-896.

Kondorosi, E., Kelemen, Z., Fulop, K., Tarayre, S., Redondo-Nieto, M., Kroll, A., Kevei, Z., and Kondorosi, A. 2005. Plant anaphase promoting complexes: Multiple activators and wide-range of substrates keep APC perpetually busy. FEBS (Fed. Eur. Biochem. Soc.) J. 272:150-150.

Mathesius, U., Charon, C., Rolfe, B. G., Kondorosi, A., and Crespi, M. 2000. Temporal and spatial order of events during the induction of cortical cell divisions in white clover by Rhizobium leguminosarum bv. trifolii inoculation or localized cytokinin addition. Mol. Plant-Microbe Interact. 13:617-628.

Mergaert, P., Nikovics, K., Kelemen, Z., Maunoury, N., Vaubert, D., Kondorosi, A., and Kondorosi, E. 2003. A novel family in Medicago truncatula consisting of more than 300 nodule-specific genes coding for small, secreted polypeptides with conserved cysteine motifs. Plant Physiol. 132:161-173.

Mergaert, P., Uchiumi, T., Alunni, B., Evanno, G., Cheron, A., Catrice, O., Mausset, A. E., Barloy-Hubler, F., Galibert, F., Kondorosi, A., and Kondorosi, E. 2006. Eukaryotic control on bacterial cell cycle and differentiation in the Rhizobium-legume symbiosis. Proc. Natl. Acad. Sci. USA 103:5230-5235.
Orosz, L., Svab, Z., Kondorosi.A, and Sik, T. 1973. Genetic studies on rhizobiophage 16-3 .1. genes and functions on chromosome. Mol. Gen. Genet. 125:341-350.

Petrovics, G., Putnoky, P., Reuhs, B., Kim, J., Thorp, T. A., Noel, K. D., Carlson, R. W., and Kondorosi, A. 1993. The presence of a novel type of surface polysaccharide in Rhizobium meliloti requires a new fattyacid synthase-like gene cluster involved in synbiottic root development. Mol. Microbiol. 8:1083-1094.

Putnoky, P., Petrovics, G., Kereszt, A., Grosskopf, E., Ha, D. T. C. Bánfalvi, Z., and Kondorosi, A. 1990. Rhizobium meliloti lipopolysaccharide and exopolysaccharide can have the same function in the plantbacterium interaction. J. Bacteriol. 172:5450-5458.

Rostas, K., Kondorosi, E., Horvath, B., Simoncsits, A., and Kondorosi, A. 1986. Conservation of extended promoter regions for nodulation genes in Rhizobium. Proc. Natl. Acad. Sci. USA 83:1757-1761.

Roudier, F., Fedorova, E., Gyorgyey, J., Feher, A., Brown, S., Kondorosi, A., and Kondorosi, E. 2000. Cell cycle function of a Medicago sativa A2-type cyclin interacting with a PSTAIRE-type cyclin-dependent kinase and a retinoblastoma protein. Plant J. 23:73-83.

Roudier, F., Fedorova, E., Lebris, M., Lecomte, P., Gyorgyey, J., Vaubert, D., Horvath, G., Abad, P., Kondorosi, A., and Kondorosi, E. 2003. The Medicago species A2-type cyclin is auxin regulated and involved in meristem formation but dispensable for endoreduplication-associated developmental programs. Plant Physiol. 131:1091-1103.

Savoure, A., Magyar, Z., Pierre, M., Brown, S., Schultze, M., Dudits, D., Kondorosi, A., and Kondorosi, E. 1994. Activation of the cell-cycle machinery and the isoflavonoid biosynthesis pathway by active Rhizobium meliloti Nod signal molecules in Medicago-microcallus suspensions. EMBO (Eur. Mol. Biol. Organ.) J. 13:1093-1102.

Schultze, M., and Kondorosi, A. 1998. Regulation of symbiotic root nodule development. Annu. Rev. Genet. 32:33-57.

Schultze, M., Quicletsire, B., Kondorosi, E., Virelizier, H., Glushka, J. N., Endre, G., Gero, S. D., and Kondorosi, A. 1992. Rhizobium meliloti produces a family of sulfated lipochitooligosaccharides exhibiting different degrees of plant host specificity. Proc. Natl. Acad. Sci. USA 89:192-196.

Schultze, M., Staehelin, C., Rohrig, H., John, M., Schmidt, J., Kondorosi, E., Schell, J., and Kondorosi, A. 1995. In-vitro sulfotransferase activity of Rhizobium meliloti NodH protein-lipochitooligosaccharides are sulfated after synthesis of the core structure. Proc. Natl. Acad. Sci. USA 92:2706-2709.

Staehelin, C., Schultze, M., Kondorosi, E., Mellor, R. B., Boller, T., and Kondorosi, A. 1994. Structural modifications in Rhizobium meliloti Nod factors influence their stability against hydrolysis by root chitinases. Plant J. 5:319-330.

Staehelin, C., Schultze, M., Kondorosi, E., and Kondorosi, A. 1995. Lipochitooligosaccharide nodulation signals from Rhizobium meliloti induce their rapid degradation by the host plant alfalfa. Plant Physiol. 108:1607-1614.

Staehelin, C., Schultze, M., Tokuyasu, K., Poinsot, V., Prome, J. C., Kondorosi, E., and Kondorosi, A. 2000. N-deacetylation of Sinorhizobium meliloti Nod factors increases their stability in the Medicago sativa rhizosphere and decreases their biological activity. Mol. PlantMicrobe Interact. 13:72-79.

Tarayre, S., Vinardell, J. M., Cebolla, A., Kondorosi, A., and Kondorosi, E. 2004. Two classes of the Cdh1-type activators of the anaphase-promoting complex in plants: Novel functional domains and distinct regulation. Plant Cell 16:422-434.

Torok, I., and Kondorosi, A. 1981. Nucleotide sequence of the R. meliloti nitrogenase reductase (nifH) gene. Nucl. Acids Res. 9:5711-5723.

Trinh, T. H., Ratet, P., Kondorosi, E., Durand, P., Kamate, K., Bauer, P., and Kondorosi, A. 1998. Rapid and efficient transformation of diploid Medicago truncatula and Medicago sativa ssp. falcata lines improved in somatic embryogenesis. Plant Cell Rep. 17:345-355.

Wong, C. H., Pankhurst, C. E., Kondorosi, A., and Broughton, W. J. 1983. Morphology of root nodules and nodule-like structures formed by Rhizobium and Agrobacterium strains containing a Rhizobium meliloti megaplasmid. J. Cell Biol. 97:787-794. 